DOI: 10.19085/journal.sijmd030801

\title{
Gen Y's Workplace Expectations on Employment Terms and Conditions: Comparative Analysis of Collegians and Office Goers
}

\author{
'Dr.Neeta Sinha \& ${ }^{2}$ Dr.Neelam Kshatriya \\ ${ }^{1}$ Asst Professor, School of Liberal Studies, Pandit Deendayal Petroleum University, Gandhinagar-382007 \\ ${ }^{2}$ C-32, Sharanam 10, Opp.Hilton Row Houses, Near Anand Nagar Crossroads, Satellite, Ahmedabad-380051 \\ OScholedge International Journal of Management \& Development (ISSN 2394-3378), Vol.03, Issue 08 (2016) pg137-163. \\ Published by: Scholedge R\&D Center [http://www.thescholedge.org/journals/] [Email: editorial@thescholedge.org]
}

\begin{abstract}
Over the past few years, an increase in stress has been witnessed amongst employees of various generations, working together at the workplace. In the process of settling at work, Millenials (Gen Y) are demonstrating new behaviors with the intent to gain success, which is starkly different from their predecessors. The objective of the study is to make a comparative analysis of the workplace related expectations of Gen Yers first as students and then as employees in order to analyze if these expectations change with time and experience, or remain the same.
\end{abstract}

Data was collected through "Two Stage Stratified Random sampling” from Millennial MBA students from four major districts of Gujarat. Out of 843 respondents, 555 i.e. 65.8 percent were students and 288 i.e. 34.2 percent being the young working professionals.

The students rated "Salary" as the first selection criteria and "job security" being second whereas Professionals rated "Job Security "as the most important factor and "Salary" was rated second, thereby stressing on the importance of these two variables in their selection criteria. "Location of the job" was rated as the least important variable both by the Students and Professionals thereby indicating that they are mobile and interested in taking up assignments that can help expand their outlook irrespective of the location. 
For these five variables; the average ranking given by the respondents was cross tabulated with 1.Age, 2.Gender and 3. Status, in order to bring out the comparative importance assigned to each variable.

India has grown in stature over the last ten years. Its GDP growth accelerated steadily, after liberalization of its economy in 1991, which lead to open policies and ceasing inward looking policies. The flow of FDI in India has increased substantially since 1991 when entry of foreign companies was allowed in the Indian economy under the pressure of balance of payments crisis of the 1980's. With this, the government leveraged the entry of private investment

In India, it is not unusual to see three generations staying together under one roof however history for the first time is witnessing something very unique i.e. three generations are also working side by side in the workplace. And this phenomenon is being observed worldwide with the entry of the latest entrants i.e. Gen $\mathrm{Y}$ to the workplace. Work place demographics, is probably at the most complex juncture with many organizations trying to balance a generation gap of more than 50 years between the oldest and youngest employees.

"Generation Gap" has been a topic of interest to the academicians since last five decades. The term was first introduced in 1960 s to describe the difference between the Silent Generation and its progeny, the Baby Boomers.

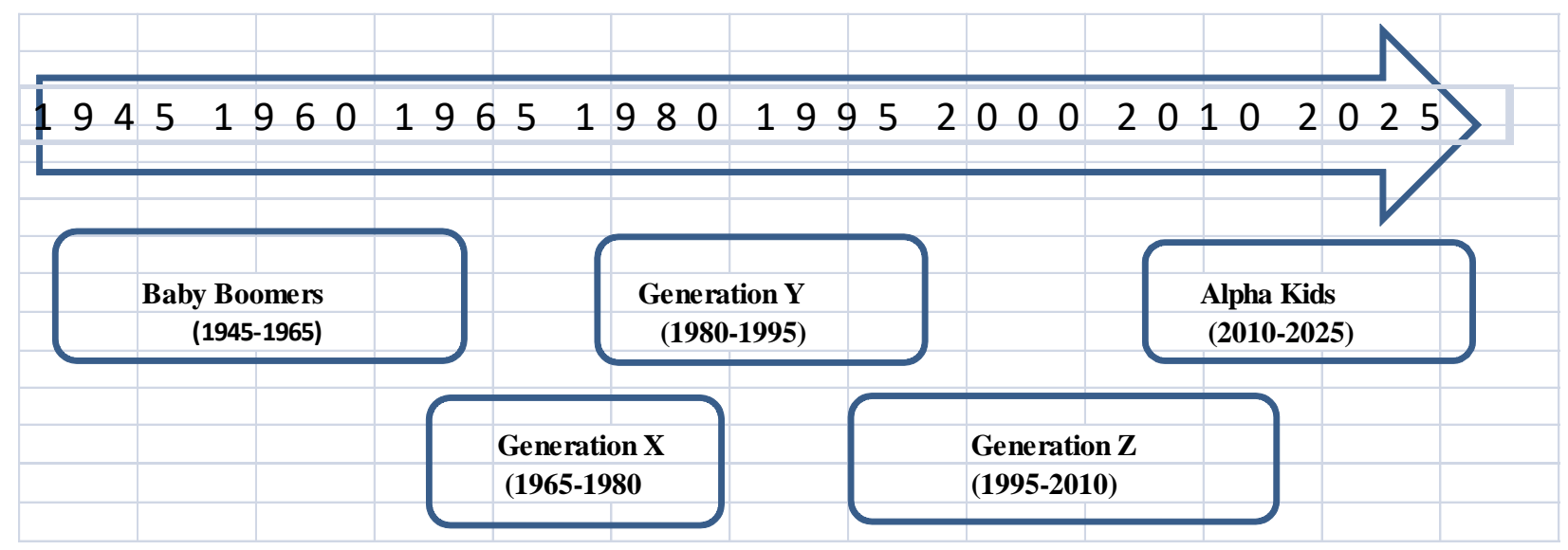

Source: Dr. Parul Saxena, M. J. (2012)

Gen $\mathrm{X}$ and Gen $\mathrm{Y}$, the two most dominant generations in today's workforce which are going to work together for at least two to three decades are also significantly different in their approach. One of the main difference between the two as per Boyd (2010) is in their source of motivation; generation 
$\mathrm{X}$ has its "focus is on self rather than society" whereas Gen $\mathrm{Y}$ "demonstrates a balance between a bigoted affinity toward self-satisfaction and social betterment". Since the sources of motivation vary between the two generations hence there is a possibility that their expectations on work related parameters would also show some variation.

The review of the literature on Generation $\mathrm{Y}$ has generally shown contrasting them to other generations (e.g. Dries at al 2008; Lancaster and Stillman 2002; Lyons 2003) the objective of this study is to understand the career expectations of the Millennials and how these expectations are manifested in their work -related choices and career decision making both for the college students and the working Gen Y Professionals.

\section{Generational Classification-The Indian perspective:}

The classification of these generations from an Indian Perspective has been studied well in the Steelcase's Work Space Futures study of Gen Y in India(October 2009). Steelcase Work Space Futures conducted a six month study of the Gen Y demographic in India in October of 2009.

It mentions that though there is no Baby Boomer generation in India, like in the US we still follow the generational definitions from the US. We have Gen Y, and Gen X in India and these groups are also represented in the same tenure, as in the US, i.e. Gen $\mathrm{Y}$ being those who were born between the year 1980-2000, Gen X as those who were between 1964-1979. Instead of Baby Boomer generation, we have the "Older Generation" born between 1947 to1964, and the "Freedom Fighters", those who were born from 1900 to 1946

The Generational Progression in India is, as mentioned ahead:

Table 3.1 Generational Progression in India

\begin{tabular}{|l|l|}
\hline \multicolumn{1}{|c|}{ Generation } & \multicolumn{1}{c|}{ Duration } \\
\hline Freedom Fighters & Born between 1900 to 1946 \\
\hline Traditionals & Born between 1947 to 1964 \\
\hline Generation X & Born between 1965 to 1979 \\
\hline Generation Y & Born between 1980 to 2000 \\
\hline
\end{tabular}


Hence though there is no direct link that India possesses to the population roar of the US, however India still follows the US by having similar generational titles and time periods. The 1940 s and 1950 s India became an independent nation. The future generation at the time had eye witnessed Mahatma Gandhi's philosophy of non-violence, his civil disobedience movement for seeking independence from the hands of the British Raj, and finally his assassination too.

\section{Literature Review}

This study was conducted at a steel plant Electrotherm (India) Ltd Group (ET) in the state of Gujarat with the objective of improving the retention rate of Gen $Y$ employees, and improving the employee engagement of the workforce. The study proved that the more actively engaged the workforce the lesser is their turnover.

The folk wisdom in Gujarat says that the roots of the tree which are responsible for giving the sweet fruits should be nurtured and not uprooted and the authors of the article stated that this philosophy should be followed by the organizations with the Appreciative Inquiry ( $\mathrm{Al}$ ) as the base. The latest entrants to the workforce are a group of Gen $\mathrm{Y}$ professionals who today form the base of the organizational pyramid and the study laid importance towards energizing the base so that GenYers are engaged. Most of the studies give an indication that Indian organizations are not doing enough to engage their employees, especially GenYers (between the age group of 21-30), which will form largest section of the employed workforce in the next three decades. The current times are witnessing economic instability across the globe and are facing common concerns of rapid reduction of organizational resources and energy and lower level of employee engagement. The ET group witnessed a high attrition approximately 33percent of Gen $\mathrm{Y}$ engineers which was close to zopercent of its workforce, the group resolved the issue and reduced the attrition percentage by putting Al (Appreciative Inquiry) to use, and improved the engagement levels of the youngsters with the organization.

Mamatha J, Nandini (2013) conducted a study at at Bangalore to find out the career expectations of Gen Y IT Employees. The study covered seventeen IT companies at Bangalore. Millenials are critical to the workforce both from the current and futuristic point of view. They not only hold high 
expectations both from the work organization and the leaders, for their own success, however their expectations are also very unpredictable.

Keeping all the above reasons in mind, the employers have become conscious of the fact that both the hiring and the retention of this young workforce is a challenge. There is a need to understand their expectations and perceptions so that organizations can assist them with the same thereby gaining their notice and in turn motivating them. This study revealed the various factors that were expected by the employees from the employer and from the job per se. It also recorded the reasons stated by these youngsters for preferring one firm over another.

Another study was conducted jointly by Pricewaterhouse Coopers, the University of Southern California and the London Business School in 2013 and is the largest and most inclusive generational study (40000 plus respondents participated) conducted at a global level on "Millennial employees" (born between 1980-1995) The study takes into account the varied factors that have its effect on the experiences of Gen $\mathrm{Y}$ employees at the workplace. These consist of the culture of the work organization, work and communication styles used at the work premises, compensation, values, career development and growth path and harmony between work and personal life .i.e. work life balance which as per this study has been revealed as the most important factor in the retention of Millenials and a main cause for them to take up a profession or a career track., which is not so traditional. This study also stated that Millenials across the globe have a lot of notable similarities; all of them desire more flexibility, want to strike balance between work and life and intend to seek opportunities which are global in nature.

The major findings of the report were:

As per another report by Pricewaterhouse Coopers (2008) the HR fraternity mentioned that they are getting a feeling that instead of interviewing the Millenials, the Millenials are interviewing them. The report also stated that nearly 88percent of Gen Yers stated that they would choose to work with an employer whose work values matched to theirs, and would prefer employers giving importance to corporate responsibility. They were also seen quoting that the employer which gave them opportunity to expand their job prospect through job travelling and international assignments would be preferred more.

Horeczy, et al. (2012) conducted a study to determine the preferred leadership styles and the particular leadership characteristics which are valued by Generation Y. This would help the 
corporates in understanding Gen $\mathrm{Y}$ better, which in turn would maximize their contribution towards their work organization. Gen Yers have a set of established leadership preferences. A survey tool was created and distributed to the members of Generation $\mathrm{Y}$ in order to determine the main characteristic and leadership preferences they valued the most. The result of the survey indicated that Gen Yers prefer proficient, hardworking, unwavering and responsible leaders. This in turn indicates their own inherent personality. And the four traits most sought by them which are mentioned above, indicate the characteristics of a transformational leadership. These results indicate that leaders/managers should adjust leadership style accordingly while dealing with Gen $\mathrm{Y}$.

\section{Objectives of Study}

1. To identify if the expectations with regards to "Employment Terms and Conditions" held by employees of Gen Y are different from that of Gen Y Collegians.

\section{Sub Objective:}

i. To identify the expectations with regards to "Employment Terms and Conditions" held by employees of Gen $Y$

ii. To identify the expectations with regards to "Employment Terms and Conditions" held by Gen Y Collegians.

$\mathrm{H}_{1}$ : There are significant differences in the expectations related to "Employment Terms and Conditions" between Gen Y Collegians and employees

$\mathrm{H}_{0}$ : There are no significant differences in the expectations related to "Employment Terms and Conditions" between Gen Y Collegians and employees.

The sampling used in this study is Stratified Random and representative of the population of Gujarat since students from across the state are found in these four major cities of Gujarat and hence there is equal representation of these four cities, in this study. 600 Questionnaire's were distributed to students, 150 each in Ahmedabad, Baroda, Surat and Rajkot. 3 Colleges were selected in each city for the purpose of the sample collection. The distribution of questionnaire was done through (1) the online mode using Google docs (2) through the distribution of hard copies to students in various colleges during their free hours by taking approval from their academics committee. A total of 555 
responses were received through both the modes. 45 of them were found to be partially filled and hence rejected.

The placement officer of these colleges was contacted to know the firms that were coming to their colleges for campus recruitment year on year. This gave an indication of the four primary sectors where majority of these students got absorbed. A total of 300 questionnaires were distributed to the working professionals out of which 283 responses were received in completely filled form. "In-Depth Interviews" and "Focused Group Discussions" were the three primary modes of Data Collection used in the study.

Secondary sources - Relevant published materials (Journals, books, newspapers, magazines), websites, and Online Database.

Demographic details

Table 5.1 Bifurcation of Sample Population

\begin{tabular}{|l|l|r|r|r|r|}
\hline \multicolumn{2}{|c|}{ Category } & Frequency & percent & Valid percent & \multicolumn{1}{c|}{ Cumulative percent } \\
\cline { 2 - 6 } & Student & 555 & 65.8 & 65.8 & 65.8 \\
\hline & Working Professional & 288 & 34.2 & 34.2 & 100.0 \\
\hline & Total & 843 & 100.0 & 100.0 & \\
\hline
\end{tabular}

A total of 843 respondents were surveyed for the purpose of this study, out of which 555 of them i.e. 65.8 percent of them were students and 288 i.e. 34.2 percent being the working professionals. 
Figure 5.1 Bifurcation of Sample Population

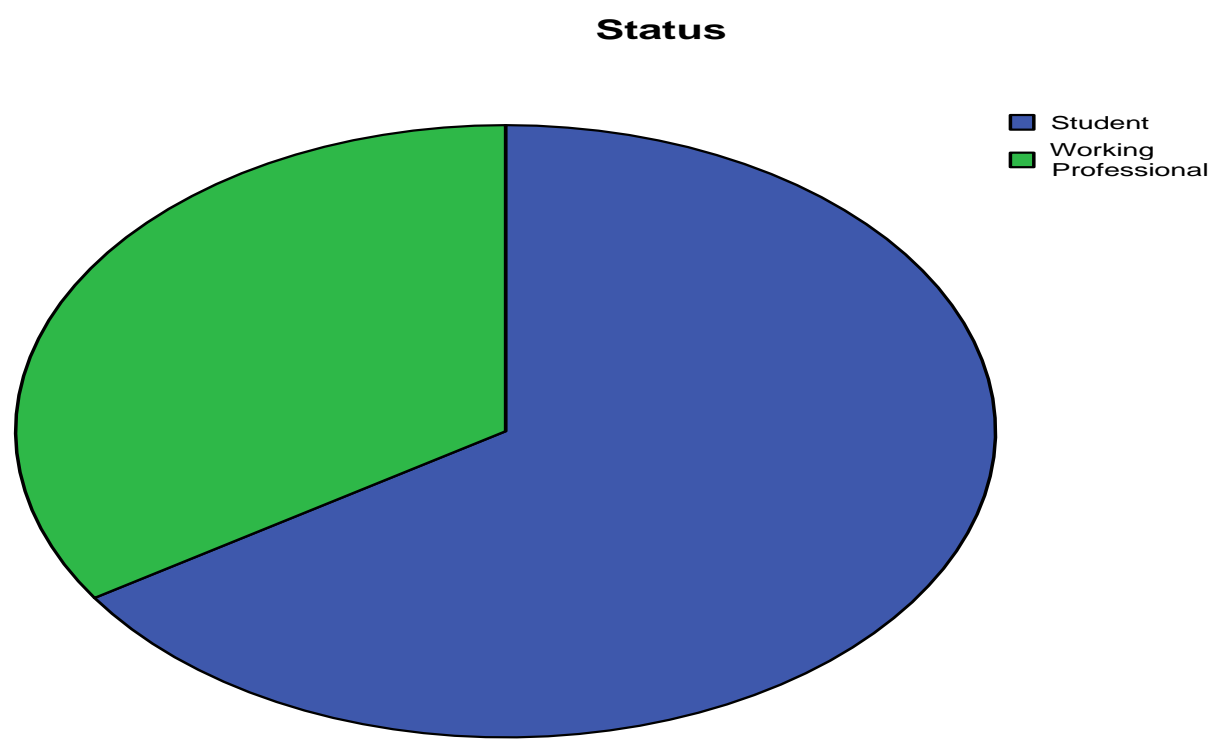

Classification of Respondents by Age and Work Status

\begin{tabular}{|c|c|c|c|}
\hline \multirow{2}{*}{ Age Group } & \multicolumn{2}{|c|}{ Work Status } & \multirow{2}{*}{ Total } \\
\hline & Student & Working Professional & \\
\hline \multirow[t]{2}{*}{ Between 19-23Yrs } & 465 & 36 & 501 \\
\hline & $83.8 \%$ & $12.5 \%$ & $59.4 \%$ \\
\hline \multirow[t]{2}{*}{$24-28 \mathrm{Yrs}$} & 65 & 129 & 194 \\
\hline & $11.7 \%$ & $44.8 \%$ & $23.0 \%$ \\
\hline \multirow[t]{2}{*}{29 Yrs \& above } & 25 & 123 & 148 \\
\hline & $4.5 \%$ & $42.7 \%$ & $17.6 \%$ \\
\hline \multirow[t]{2}{*}{ Total } & 555 & 288 & 843 \\
\hline & $100.0 \%$ & $100.0 \%$ & $100.0 \%$ \\
\hline
\end{tabular}


Figure 5.2 Classification of Respondents by Age and Work Status

\section{Bar Chart}

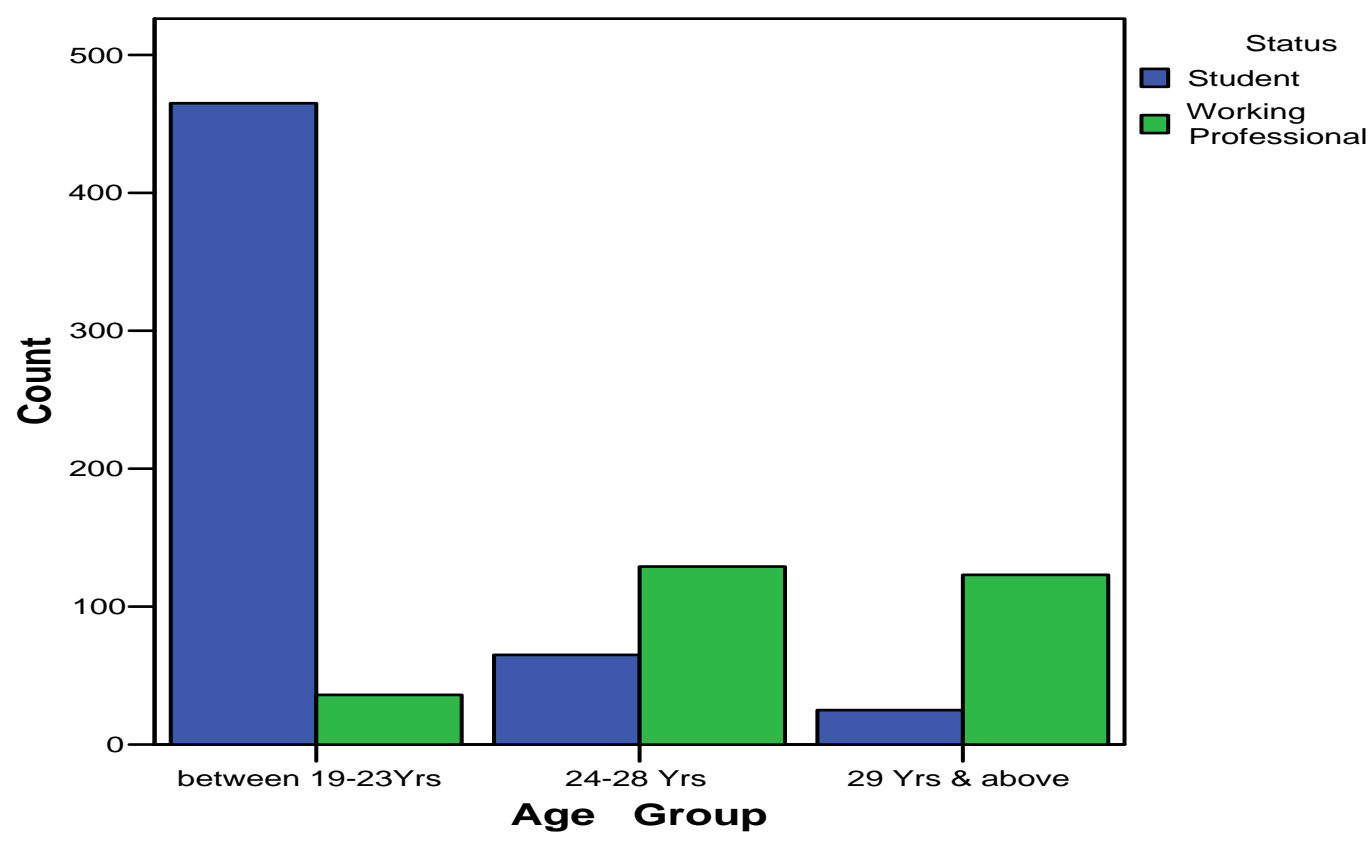

The sample population in the study is the Millennial MBA students pursuing their management degree and Millennial Employees with the work experience varying between < 1 year to 3 years and above. Amongst the student population 83.8 percent students are between the age group of 19-23 years and most of the working professionals between of 24-28 years.

Classification of Respondents by Gender and Work Status

\begin{tabular}{|c|c|c|c|}
\hline \multirow[t]{2}{*}{ Gender } & \multicolumn{2}{|c|}{ Status } & \multirow{2}{*}{ Total } \\
\hline & Student & Working Professional & \\
\hline \multirow[t]{2}{*}{ Male } & 355 & 171 & 526 \\
\hline & $64.0 \%$ & $59.4 \%$ & $62.4 \%$ \\
\hline \multirow[t]{2}{*}{ Female } & 200 & 117 & 317 \\
\hline & $36.0 \%$ & $40.6 \%$ & $37.6 \%$ \\
\hline \multirow[t]{2}{*}{ Total } & 555 & 288 & 843 \\
\hline & $100.0 \%$ & $100.0 \%$ & $100.0 \%$ \\
\hline
\end{tabular}


Figure 5.3 Classification of Respondents by Gender and Work Status

\section{Bar Chart}

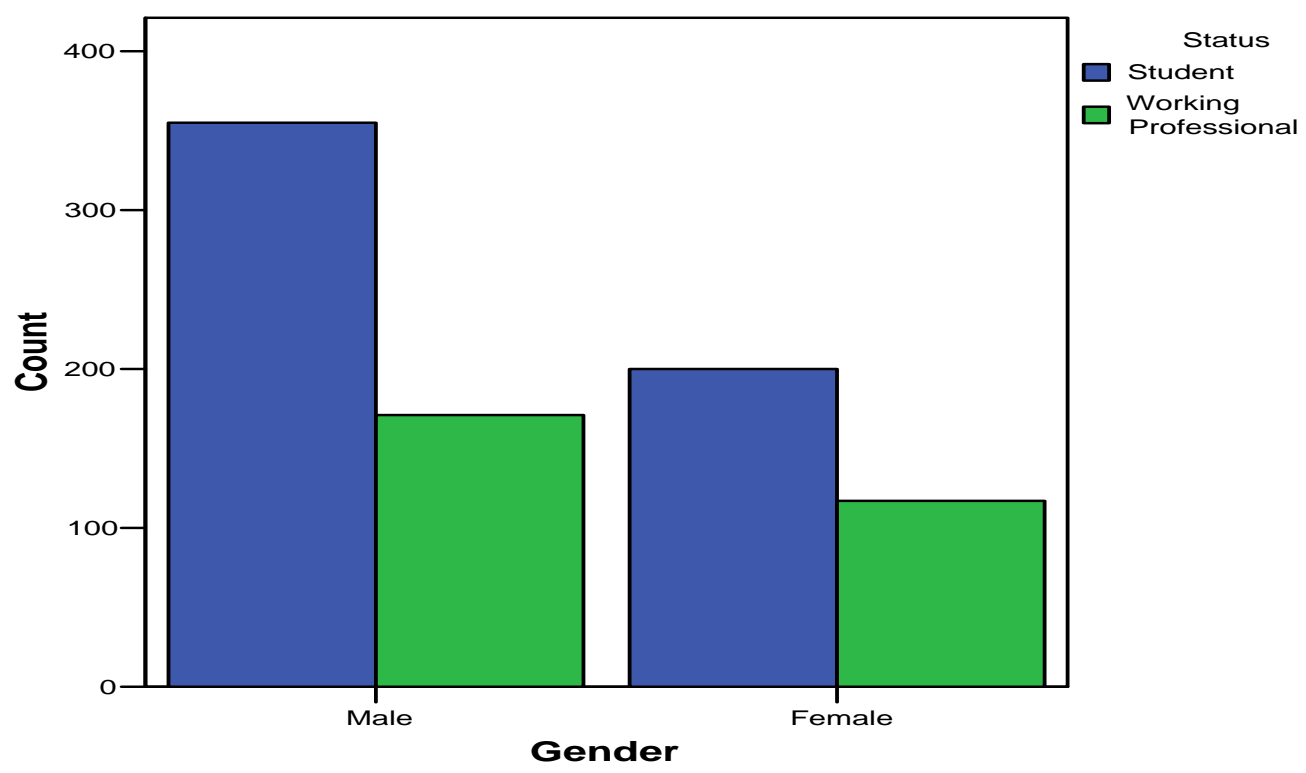

The classification of respondents by their gender and work status is presented in table and figure above. Among the student population 64 percent of respondents are males and 36 percent are females. Amidst the working professionals 59.4 percent of them are males and 40.6 percent are females.

\section{Analysis of the Five Variables while selecting a preferred employer}

In order to identify the work place expectations 5 variables were selected. The variables ranked are: Job security, Challenging job profile, reputation of the organization or the brand name, the salary being paid for the work and the location of the job. (To be rated by the Collegians and Working professionals while selecting a preferred employer, on a scale of 1 to 5 , in order of their importance in their life (where 1 means least important and 5 means most important) Each of them is discussed as a cross tabulated data for the students and the professionals:

1. Job security 
Table 5.6 Job security * Status Cross tabulation

\begin{tabular}{|c|c|c|c|c|}
\hline \multicolumn{2}{|c|}{ Job security } & \multicolumn{2}{|r|}{ Status } & \multirow{3}{*}{$\begin{array}{c}\text { Total } \\
21 \\
\end{array}$} \\
\hline & & \multirow{2}{*}{\begin{tabular}{|l|} 
Student \\
15 \\
\end{tabular}} & \multirow{2}{*}{\begin{tabular}{|c|} 
Working Professional \\
6 \\
\end{tabular}} & \\
\hline 1 & Count & & & \\
\hline & $\%$ within Status & $2.7 \%$ & $2.1 \%$ & $2.5 \%$ \\
\hline 2 & Count & 5 & 24 & 29 \\
\hline & $\%$ within Status & $.9 \%$ & $8.3 \%$ & $3.4 \%$ \\
\hline 3 & Count & 60 & 36 & 96 \\
\hline & $\%$ within Status & $10.8 \%$ & $12.5 \%$ & $11.4 \%$ \\
\hline 4 & Count & 220 & 114 & 334 \\
\hline & $\%$ within Status & $39.6 \%$ & $39.6 \%$ & $39.6 \%$ \\
\hline 5 & Count & 255 & 108 & 363 \\
\hline & $\%$ within Status & $45.9 \%$ & $37.5 \%$ & $43.1 \%$ \\
\hline \multirow[t]{2}{*}{ Total } & Count & 555 & 288 & 843 \\
\hline & $\%$ within Status & $100.0 \%$ & $100.0 \%$ & $100.0 \%$ \\
\hline
\end{tabular}

Analysis: Job security has been rated more important by Students with 85.5 percent of them rating it as either important or most important and only 77.1 percent of professionals giving it a rating of $4 / 5$

2. Challenging job profile

Table 5.7 Challenging job profile * Status Cross tabulation

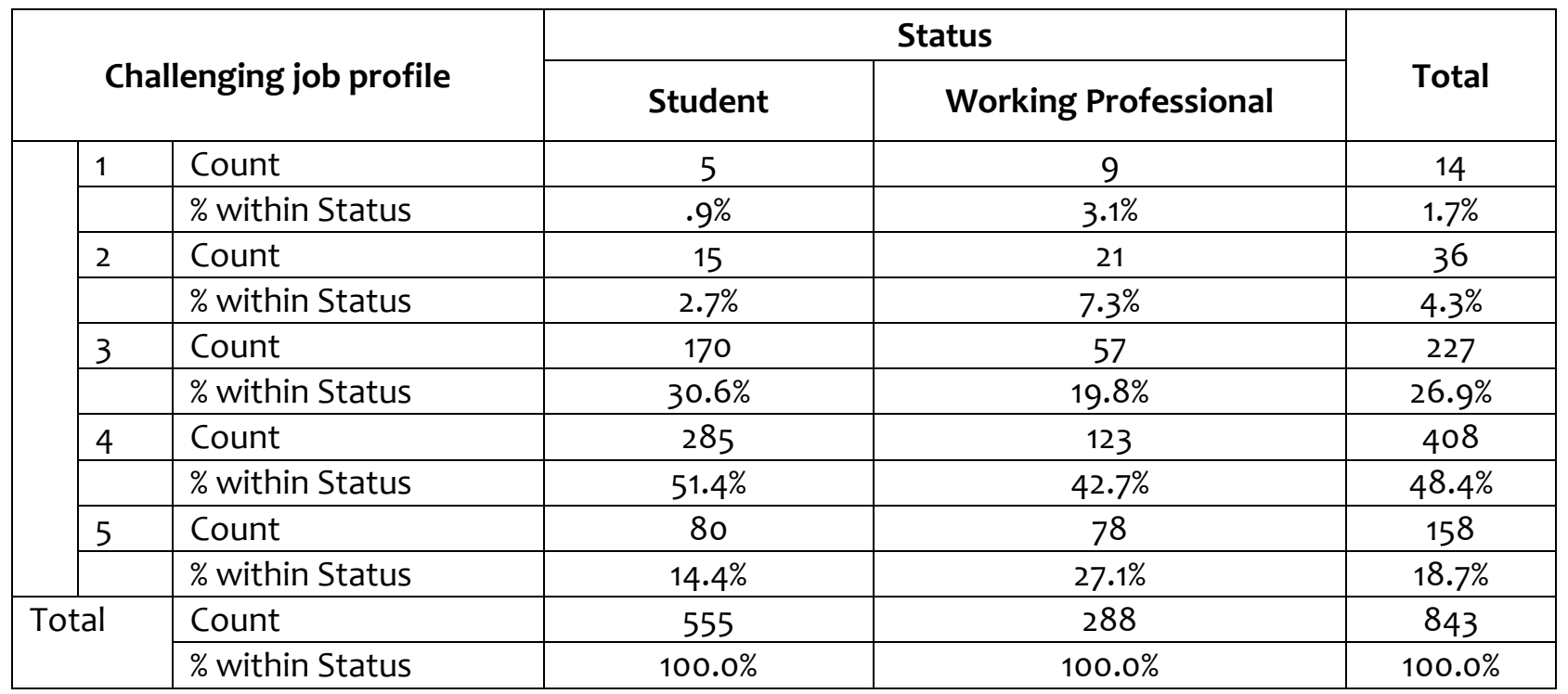

Analysis: Challenging job profile has been rated more important by Professionals with 69.8 percent of 
them rating it as either important or most important and 65.8 percent of students rating it as $4 / 5$.

3. Reputation of the Organization/Brand name

Table 5.8 Reputation of the Organization/Brand name * Status Cross tabulation

\begin{tabular}{|c|c|c|c|c|c|}
\hline \multirow{2}{*}{\multicolumn{3}{|c|}{\begin{tabular}{|c|} 
Reputation of the \\
Organization/Brand name
\end{tabular}}} & \multicolumn{2}{|r|}{ Status } & \multirow{3}{*}{$\begin{array}{c}\text { Total } \\
17 \\
\end{array}$} \\
\hline & & & \multirow{2}{*}{$\begin{array}{r}\text { Student } \\
5 \\
\end{array}$} & \multirow{2}{*}{\begin{tabular}{|c|} 
Working Professional \\
12 \\
\end{tabular}} & \\
\hline & 1 & Count & & & \\
\hline & & $\%$ within Status & $.9 \%$ & $4.2 \%$ & $2.0 \%$ \\
\hline & 2 & Count & 20 & 39 & 59 \\
\hline & & $\%$ within Status & $3.6 \%$ & $13.5 \%$ & $7.0 \%$ \\
\hline & 3 & Count & 60 & 72 & 132 \\
\hline & & $\%$ within Status & $10.8 \%$ & $25.0 \%$ & $15.7 \%$ \\
\hline & 4 & Count & 160 & 81 & 241 \\
\hline & & $\%$ within Status & $28.8 \%$ & $28.1 \%$ & $28.6 \%$ \\
\hline & 5 & Count & 310 & 84 & 394 \\
\hline & & $\%$ within Status & $55.9 \%$ & $29.2 \%$ & $46.7 \%$ \\
\hline \multirow{2}{*}{\multicolumn{2}{|c|}{ Total }} & Count & 555 & 288 & 843 \\
\hline & & $\%$ within Status & $100.0 \%$ & $100.0 \%$ & $100.0 \%$ \\
\hline
\end{tabular}

Analysis: Reputation of the Organization/Brand name has been rated more important by Students with 84.7 percent of them rating it as either important or most important and only 57.3 percent of Professionals giving it a rating of either 4 or 5

4. Salary

Table 5.9 Salary * Status Cross tabulation

\begin{tabular}{|c|l|c|c|c|}
\hline \multicolumn{2}{|c|}{ Salary } & \multicolumn{2}{l}{ Status } & \multirow{2}{*}{ Total } \\
\cline { 3 - 5 } \multicolumn{2}{|c|}{ Student } & Working Professional & \\
\hline 1 & Count & 5 & 18 & 23 \\
\hline & $\%$ within Status & .9 & $6.3 \%$ & $2.7 \%$ \\
\hline 2 & Count & 0 & 12 & 12 \\
\hline & $\%$ within Status & $.0 \%$ & $4.2 \%$ & 83 \\
\hline 3 & Count & 35 & $16.7 \%$ & $9.8 \%$ \\
\hline & $\%$ within Status & $6.3 \%$ & 111 & 326 \\
\hline 4 & Count & 215 & $38.5 \%$ & $38.7 \%$ \\
\hline & $\%$ within Status & $38.7 \%$ & 99 & 399 \\
\hline 5 & Count & 300 & & \\
\hline
\end{tabular}




\begin{tabular}{|l|l|c|c|c|}
\hline & \% within Status & $54.1 \%$ & $34.4 \%$ & $47.3 \%$ \\
\hline \multirow{2}{*}{ Total } & Count & 555 & 288 & 843 \\
\cline { 2 - 5 } & $\%$ within Status & $100.0 \%$ & $100.0 \%$ & $100.0 \%$ \\
\hline
\end{tabular}

Analysis: Between the Students and Professionals Salary has been rated more important by Students with 92.8 percent of them rating it as either important or most important whereas only 72.9 percent of Professionals have given it a rating of $4 / 5$.

5. Location of job

Table 5.10 Location of job * Status Cross tabulation

\begin{tabular}{|c|l|l|c|c|c|}
\hline \multicolumn{2}{|c|}{ Location of the job } & \multicolumn{2}{c|}{ Status } & \multirow{2}{*}{ Total } \\
\cline { 3 - 5 } \multicolumn{2}{|c|}{} & \multicolumn{2}{|l|}{ Student } & Working Professional & \\
\hline & 1 & Count & 15 & 36 & 51 \\
\hline & & $\%$ within Status & $2.7 \%$ & $12.5 \%$ & $6.0 \%$ \\
\hline & 2 & Count & 35 & $14.6 \%$ & 77 \\
\hline & & $\%$ within Status & $6.3 \%$ & 57 & $9.1 \%$ \\
\hline & 3 & Count & 145 & $19.8 \%$ & 202 \\
\hline & & $\%$ within Status & $26.1 \%$ & 90 & $24.0 \%$ \\
\hline & 4 & Count & 225 & $31.3 \%$ & 315 \\
\hline & & $\%$ within Status & $40.5 \%$ & 63 & $37.4 \%$ \\
\hline & 5 & Count & 135 & $21.9 \%$ & 198 \\
\hline & & $\%$ within Status & $24.3 \%$ & 288 & $23.5 \%$ \\
\hline \multicolumn{2}{|l|}{ Total } & Count & 555 & $100.0 \%$ & 843 \\
\hline & & $\%$ within Status & $100.0 \%$ & $100.0 \%$ \\
\hline
\end{tabular}

Analysis: Location of the job has been rated more important by Students with 64.8 percent of them rating it as either important or most important whereas only 53.2 percent of Professionals have rated it as $4 / 5$.

Summary-The Analysis of the five tables above is indicative of the fact that apart from Location of the job being rated last choice by both Students and Professionals (Which indicates that they are mobile, and location of the job does not stop them from working with their preferred employer) their choices vary on the other four aspects and so would their expectations from their employer. Salary is the first preference of students whereas Professionals have indicated job security as the most 
important factor. The table below sums up the choices indicated by the respondents in descending order (The percentages mentioned in the bracket are the cumulative percentage of their 4 th and $5^{\text {th }}$ rating, which means the factor is either important or very important

Table 5.11 Rating preferences of Students and Professionals presented in descending order

\section{Students}

- $\quad$ Salary (92.8\%)

- Job security (85.5\%)

- "Reputation of the Organization/Brand name" (84.7\%)

- “Challenging job profile" (65.8\%)

- Location of job (64.8\%)

\section{Professionals}

- Job security (77.1\%)

- $\quad$ Salary (72.9\%)

- “Challenging job profile" (69.8\%)

- "Reputation of the Organization/Brand name" (57.3\%)

- Location of job (53.2\%)

1. Mann -Whitney Test, followed by 2. Chi Square Test

Table 5.24 Mann-Whitney Test-For Employment Terms and Conditions

Ranks

\begin{tabular}{|c|c|c|c|c|}
\hline Sub Factors & Status & $\mathbf{N}$ & $\begin{array}{c}\text { Mean } \\
\text { Rank }\end{array}$ & $\begin{array}{c}\text { Sum of } \\
\text { Ranks }\end{array}$ \\
\hline \multirow{3}{*}{$\begin{array}{l}\text { 1."Timely well paid salary "is the deciding factor for me to } \\
\text { pick up a job }\end{array}$} & Student & 555 & 390.30 & 216615.00 \\
\hline & \begin{tabular}{|l|} 
Working \\
Professional
\end{tabular} & 288 & 483.09 & 139131.00 \\
\hline & Total & 843 & & \\
\hline \multirow{3}{*}{$\begin{array}{l}\text { 2. "Flexible Work Timings' and "Weekends off " is a } \\
\text { motivator for me to pick up a job }\end{array}$} & Student & 555 & 395.99 & 219772.50 \\
\hline & \begin{tabular}{|l|} 
Working \\
Professional \\
\end{tabular} & 288 & 472.13 & 135973.50 \\
\hline & Total & 843 & & \\
\hline \multirow{3}{*}{$\begin{array}{l}\text { 3."Health Insurance, Paid Vacation Time, Provident Fund } \\
\text { and Retirement benefits" are more important than the } \\
\text { monthly "Salary" }\end{array}$} & Student & 555 & 412.34 & 228847.50 \\
\hline & \begin{tabular}{|l|} 
Working \\
Professional
\end{tabular} & 288 & 440.62 & 126898.50 \\
\hline & Total & 843 & & \\
\hline \multirow{3}{*}{$\begin{array}{l}\text { 4. "Casual Dress Code" is better than the traditional } \\
\text { "Formal attire" at the workplace }\end{array}$} & Student & 555 & 423.73 & 235170.00 \\
\hline & $\begin{array}{l}\text { Working } \\
\text { Professional }\end{array}$ & 288 & 418.67 & 120576.00 \\
\hline & Total & 843 & & \\
\hline \multirow{2}{*}{$\begin{array}{l}\text { 5."Work in Teams at the workplace" or "Work from Home" } \\
\text { both options should exist at the workplace }\end{array}$} & Student & 555 & 418.57 & 232305.00 \\
\hline & $\begin{array}{l}\text { Working } \\
\text { Professional }\end{array}$ & 288 & 428.61 & 123441.00 \\
\hline
\end{tabular}




\begin{tabular}{|c|c|c|c|c|}
\hline & Total & 843 & & \\
\hline \multirow{3}{*}{$\begin{array}{l}\text { 6."Job security' is not a concern , since there are plenty of } \\
\text { jobs around }\end{array}$} & Student & 555 & 457.59 & 253965.00 \\
\hline & \begin{tabular}{|l|} 
Working \\
Professional
\end{tabular} & 288 & 353.41 & 101781.00 \\
\hline & Total & 843 & & \\
\hline \multirow{3}{*}{$\begin{array}{l}\text { 7.Its very common to find a gap between the "initial job } \\
\text { description" and "the actual work made to be done on } \\
\text { job", and this is a breach of trust }\end{array}$} & Student & 555 & 399.09 & 221497.50 \\
\hline & \begin{tabular}{|l|} 
Working \\
Professional
\end{tabular} & 288 & 466.14 & 134248.50 \\
\hline & Total & 843 & & \\
\hline \multirow{3}{*}{$\begin{array}{l}\text { 8."Location of job" is no constraint for me, since I am } \\
\text { flexible and mobile }\end{array}$} & Student & 555 & 400.24 & 222135.00 \\
\hline & \begin{tabular}{|l|} 
Working \\
Professional
\end{tabular} & 288 & 463.93 & 133611.00 \\
\hline & Total & 843 & & \\
\hline \multirow{3}{*}{$\begin{array}{l}\text { 9. Maternity/Paternity/Adoption leaves/Sabbaticals } \\
\text { Privilege/Casual/and Sick leaves, all should be made } \\
\text { available to employees as and when needed }\end{array}$} & Student & 555 & 384.70 & 213510.00 \\
\hline & \begin{tabular}{|l|} 
Working \\
Professional \\
\end{tabular} & 288 & 493.88 & 142236.00 \\
\hline & Total & 843 & & \\
\hline \multirow{3}{*}{$\begin{array}{l}\text { 10.Sports Room and Recreation facilities at the work place } \\
\text {,make me more efficient }\end{array}$} & Student & 555 & 416.11 & 230940.00 \\
\hline & \begin{tabular}{|l} 
Working \\
Professional \\
\end{tabular} & 288 & 433.35 & 124806.00 \\
\hline & Total & 843 & & \\
\hline \multirow{3}{*}{$\begin{array}{l}\text { 11.Options to work "Part Time" should be made available, if } \\
\text { need be }\end{array}$} & Student & 555 & 418.43 & 232230.00 \\
\hline & $\begin{array}{l}\text { Working } \\
\text { Professional }\end{array}$ & 288 & 428.88 & 123516.00 \\
\hline & Total & 843 & & \\
\hline \multirow{3}{*}{$\begin{array}{l}\text { 12.Discrimination basis Gender, race, marital status still } \\
\text { exists at the workplace }\end{array}$} & Student & 555 & 440.82 & 244657.50 \\
\hline & \begin{tabular}{|l|} 
Working \\
Professional
\end{tabular} & 288 & 385.72 & 111088.50 \\
\hline & Total & 843 & & \\
\hline \multirow{3}{*}{$\begin{array}{l}\text { 13. Grievance Redressal Forums, do give justice, if any } \\
\text { injustice happens to me at the work place }\end{array}$} & Student & 555 & 422.11 & 234270.00 \\
\hline & \begin{tabular}{|l|} 
Working \\
Professional
\end{tabular} & 288 & 421.79 & 121476.00 \\
\hline & Total & 843 & & \\
\hline
\end{tabular}

Table 5.25 Sub variables of Employment Terms and Conditions

V1."Timely well paid salary "is the deciding factor for me to pick up a job

V2 Flexible Work Timings' and "Weekends off" is a motivator for me to pick up a job

V3."Health Insurance, Paid Vacation Time, Provident Fund and Retirement benefits" are more important than the monthly "Salary"

V4 Casual Dress Code" is better than the traditional "Formal attire" at the workplace 
V5."Work in Teams at the workplace" or "Work from Home" both options should exist at the workplace

V6."Job security' is not a concern, since there are plenty of jobs around

V7 It's very common to find a gap between the "initial job description" and "the actual work made to be done on job", and this is a breach of trust

V8."Location of job" is no constraint for me, since I am flexible and mobile

V9 Maternity/Paternity/Adoption leaves/Sabbaticals Privilege/Casual/and Sick leaves, all should be made available to employees as and when needed

V10 .Sports Room and Recreation facilities at the work place make me more efficient

V11 Options to work "Part Time" should be made available, if need be

V12 Discrimination basis Gender, race, marital status still exists at the workplace

V13 "Grievance Redressal Forums" do give justice, if any injustice happens to me at the work place

Table 5.26 Grouping Variable: Status for "Employment Terms and Conditions"

\begin{tabular}{|c|c|c|c|c|c|c|c|c|c|c|c|c|c|}
\hline $\begin{array}{l}\text { Tes } \\
t\end{array}$ & V1 & V2 & $v_{3}$ & $V_{4}$ & $V_{5}$ & V6 & $v_{7}$ & V8 & V9 & V10 & V11 & V12 & V13 \\
\hline $\begin{array}{l}\text { Ma } \\
\text { nn- } \\
\text { Wh } \\
\text { itn } \\
\text { ey } \\
\text { U }\end{array}$ & $\begin{array}{r}623 \\
25.0 \\
00\end{array}$ & $\begin{array}{r}654 \\
82.5 \\
00\end{array}$ & $\begin{array}{r}745 \\
57.5 \\
00\end{array}$ & $\begin{array}{r}789 \\
60 . \\
000\end{array}$ & $\begin{array}{r}780 \\
15.0 \\
00\end{array}$ & $\begin{array}{r}601 \\
65.0 \\
00\end{array}$ & $\begin{array}{r}672 \\
07.5 \\
00\end{array}$ & $\begin{array}{r}678 \\
45.0 \\
00\end{array}$ & $\begin{array}{r}592 \\
20.0 \\
00\end{array}$ & $\begin{array}{r}766 \\
50.0 \\
00\end{array}$ & $\begin{array}{r}779 \\
40.0 \\
00\end{array}$ & $\begin{array}{r}694 \\
72.5 \\
00\end{array}$ & $\begin{array}{r}798 \\
60.0 \\
00\end{array}$ \\
\hline $\begin{array}{l}\text { Wil } \\
\text { cox } \\
\text { on } \\
\text { W }\end{array}$ & $\begin{array}{c}216 \\
615 \\
000\end{array}$ & $\begin{array}{r}2197 \\
72.5 \\
00\end{array}$ & $\begin{array}{r}228 \\
847 \\
500\end{array}$ & $\begin{array}{r}1205 \\
76.0 \\
00\end{array}$ & $\begin{array}{r}2323 \\
05.0 \\
00\end{array}$ & $\begin{array}{r}1017 \\
81.0 \\
00\end{array}$ & $\begin{array}{r}2214 \\
97.5 \\
00\end{array}$ & $\begin{array}{r}2221 \\
35.0 \\
00\end{array}$ & $\begin{array}{r}2135 \\
10.0 \\
00\end{array}$ & $\begin{array}{r}230 \\
940 . \\
000\end{array}$ & $\begin{array}{r}2322 \\
30.0 \\
00\end{array}$ & $\begin{array}{r}1110 \\
88.5 \\
00\end{array}$ & $\begin{array}{r}1214 \\
76.0 \\
00\end{array}$ \\
\hline Z & $\begin{array}{r}5.41 \\
3 \\
\end{array}$ & $\begin{array}{r}4.43 \\
7 \\
\end{array}$ & $\begin{array}{r}1.65 \\
0 \\
\end{array}$ & .295 & .583 & $\begin{array}{r}6.05 \\
7 \\
\end{array}$ & $\begin{array}{r}3.94 \\
1 \\
\end{array}$ & $\begin{array}{r}3.71 \\
8 \\
\end{array}$ & $\begin{array}{r}6.36 \\
4 \\
\end{array}$ & $\begin{array}{r}1.00 \\
7 \\
\end{array}$ & -.611 & $\begin{array}{r}3.20 \\
6 \\
\end{array}$ & .018 \\
\hline $\begin{array}{l}\text { Asy } \\
\mathrm{mp}\end{array}$ & .000 & .000 & .099 & .768 & .560 & .000 & .000 & .000 & .000 & .314 & .541 & .001 & .985 \\
\hline
\end{tabular}




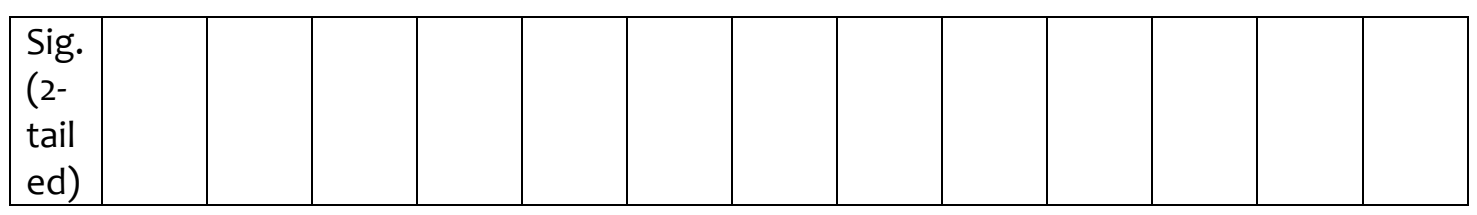

Small significance values (<.05) indicate that the two groups have different locations

For these seven sub factors where the significance value is $<0.05$ Chi Square Test was run. The chisquare measures test the hypothesis that the row and column variables in a cross tabulation are independent. A low significance value (typically below 0.05) indicates that there may be some relationship between the two variables.

1. Table 5.27.1 "Timely well paid salary "is the deciding factor for me to pick up a job * Status Crosstab

\begin{tabular}{|c|c|c|c|c|}
\hline \multirow{2}{*}{\multicolumn{2}{|c|}{$\begin{array}{l}\text { 1."Timely well paid salary "is the deciding } \\
\text { factor for me to pick up a job }\end{array}$}} & \multicolumn{2}{|c|}{ Status } & \multirow{3}{*}{\begin{aligned} \multicolumn{1}{l}{ Total } \\
170\end{aligned}} \\
\hline & & \multirow{2}{*}{$\begin{array}{l}\text { Student } \\
125\end{array}$} & \multirow{2}{*}{$\begin{array}{l}\text { Professional } \\
45\end{array}$} & \\
\hline Strongly Agree & Count & & & \\
\hline & $\%$ within Status & $22.5 \%$ & $15.6 \%$ & $20.2 \%$ \\
\hline \multirow[t]{2}{*}{ Agree } & Count & 225 & 66 & 291 \\
\hline & \% within Status & $40.5 \%$ & $22.9 \%$ & $34.5 \%$ \\
\hline \multirow[t]{2}{*}{$\begin{array}{l}\text { Neither Agree nor } \\
\text { Disagree }\end{array}$} & Count & 60 & 57 & 117 \\
\hline & \% within Status & $10.8 \%$ & $19.8 \%$ & $13.9 \%$ \\
\hline \multirow[t]{2}{*}{ Disagree } & Count & 60 & 57 & 117 \\
\hline & $\%$ within Status & $10.8 \%$ & $19.8 \%$ & $13.9 \%$ \\
\hline \multirow[t]{2}{*}{ Strongly Disagree } & Count & 85 & 63 & 148 \\
\hline & $\%$ within Status & $15 \cdot 3 \%$ & $21.9 \%$ & $17.6 \%$ \\
\hline \multirow[t]{2}{*}{ Total } & Count & 555 & 288 & 843 \\
\hline & $\%$ within Status & $100.0 \%$ & $100.0 \%$ & $100.0 \%$ \\
\hline
\end{tabular}

Table 5.27.2

Chi-Square Test

\begin{tabular}{|l|r|r|r|}
\hline & \multicolumn{1}{|c|}{ Value } & \multicolumn{1}{|c|}{ Df } & \multicolumn{1}{c|}{ Asymp. Sig. (2-sided) } \\
\hline Pearson Chi-Square & $\mathbf{4 8 . 2 1 9 ( a )}$ & $\mathbf{4}$ & $\mathbf{0 0 0}$ \\
\hline Likelihood Ratio & 48.390 & 4 & .000 \\
\hline Linear-by-Linear Association & 28.165 & 1 & .000 \\
\hline N of Valid Cases & 843 & & \\
\hline
\end{tabular}

a o cells $(.0 \%)$ have expected count less than 5 . The minimum expected count is 39.97 . 
The value of $\mathrm{P}<0.05$, hence Null Hypothesis is rejected. This indicates that there is difference in the expectations of collegians and employees on this sub variable.

2.Table 5.28.1 "Flexible Work Timings' and "Weekends off" is a motivator for me to pick up a job * Status Crosstab

\begin{tabular}{|c|c|c|c|c|}
\hline \multirow{2}{*}{\multicolumn{2}{|c|}{$\begin{array}{l}\text { 2. "Flexible Work Timings' and "Weekends off " is a } \\
\text { motivator for me to pick up a job }\end{array}$}} & \multicolumn{2}{|c|}{ Status } & \multirow{3}{*}{$\begin{aligned} \text { Total } \\
158\end{aligned}$} \\
\hline & & \multirow{2}{*}{$\begin{array}{r}\text { Student } \\
110\end{array}$} & \multirow{2}{*}{$\begin{array}{r}\text { Professional } \\
48 \\
\end{array}$} & \\
\hline Strongly Agree & Count & & & \\
\hline & $\%$ within Status & $19.8 \%$ & $16.7 \%$ & $18.7 \%$ \\
\hline Agree & Count & 220 & 57 & 277 \\
\hline & \% within Status & $39.6 \%$ & $19.8 \%$ & $32.9 \%$ \\
\hline \multirow[t]{2}{*}{$\begin{array}{l}\text { Neither Agree nor } \\
\text { Disagree }\end{array}$} & Count & 85 & 84 & 169 \\
\hline & \% within Status & $15.3 \%$ & $29.2 \%$ & $20.0 \%$ \\
\hline \multirow[t]{2}{*}{ Disagree } & Count & 95 & 69 & 164 \\
\hline & \% within Status & $17.1 \%$ & $24.0 \%$ & $19.5 \%$ \\
\hline \multirow[t]{2}{*}{ Strongly Disagree } & Count & 45 & 30 & 75 \\
\hline & \% within Status & $8.1 \%$ & $10.4 \%$ & $8.9 \%$ \\
\hline \multirow[t]{2}{*}{ Total } & Count & 555 & 288 & 843 \\
\hline & \% within Status & $100.0 \%$ & $100.0 \%$ & $100.0 \%$ \\
\hline
\end{tabular}

Table 5.28.2

\section{Chi-Square Test}

\begin{tabular}{|l|r|r|r|}
\hline & \multicolumn{1}{|c|}{ Value } & \multicolumn{1}{c|}{ Df } & \multicolumn{1}{c|}{ Asymp. Sig. (2-sided) } \\
\hline Pearson Chi-Square & $47.581(\mathrm{a})$ & $\mathbf{4}$ & $\mathbf{0 0 0}$ \\
\hline Likelihood Ratio & 48.523 & 4 & .000 \\
\hline Linear-by-Linear Association & 17.636 & 1 & .000 \\
\hline N of Valid Cases & 843 & & \\
\hline
\end{tabular}

a 0 cells $(.0 \%)$ have expected count less than 5 . The minimum expected count is 25.62 .

The value of $\mathrm{P}<0.05$, hence Null Hypothesis is rejected. This indicates that there is difference in the expectations of collegians and employees on this sub variable

3. Table 5.29.1 "Job security" is not a concern, since there are plenty of jobs around" * Status Crosstab 


\begin{tabular}{|c|c|c|c|c|}
\hline \multirow{2}{*}{\multicolumn{2}{|c|}{$\begin{array}{l}\text { 6."Job security' is not a concern , since there are } \\
\text { plenty of jobs around }\end{array}$}} & \multicolumn{2}{|c|}{ Status } & \multirow{3}{*}{$\begin{array}{r}\text { Total } \\
145\end{array}$} \\
\hline & & \multirow{2}{*}{$\begin{array}{l}\text { Student } \\
85\end{array}$} & \multirow{2}{*}{$\begin{array}{r}\text { Professional } \\
60 \\
\end{array}$} & \\
\hline Strongly Agree & Count & & & \\
\hline & $\%$ within Status & $15.3 \%$ & $20.8 \%$ & $17.2 \%$ \\
\hline \multirow[t]{2}{*}{ Agree } & Count & 90 & 87 & 177 \\
\hline & \% within Status & $16.2 \%$ & $30.2 \%$ & $21.0 \%$ \\
\hline \multirow[t]{2}{*}{$\begin{array}{l}\text { Neither Agree nor } \\
\text { Disagree }\end{array}$} & Count & 105 & 69 & 174 \\
\hline & $\%$ within Status & $18.9 \%$ & $24.0 \%$ & $20.6 \%$ \\
\hline \multirow[t]{2}{*}{ Disagree } & Count & 210 & 51 & 261 \\
\hline & $\%$ within Status & $37.8 \%$ & $17.7 \%$ & $31.0 \%$ \\
\hline \multirow[t]{2}{*}{ Strongly Disagree } & Count & 65 & 21 & 86 \\
\hline & $\%$ within Status & $11.7 \%$ & $7.3 \%$ & $10.2 \%$ \\
\hline \multirow[t]{2}{*}{ Total } & Count & 555 & 288 & 843 \\
\hline & $\%$ within Status & $100.0 \%$ & $100.0 \%$ & $100.0 \%$ \\
\hline
\end{tabular}

Table 5.29.2

Chi-Square Test

\begin{tabular}{|l|r|r|r|}
\hline & \multicolumn{1}{|c|}{ Value } & \multicolumn{1}{c|}{ Df } & \multicolumn{1}{|c|}{ Asymp. Sig. (2-sided) } \\
\hline Pearson Chi-Square & $\mathbf{5 1 . 8 1 5 ( a )}$ & $\mathbf{4}$ & $\mathbf{0 0 0}$ \\
\hline Likelihood Ratio & 53.434 & 4 & .000 \\
\hline Linear-by-Linear Association & 34.212 & 1 & .000 \\
\hline N of Valid Cases & 843 & & \\
\hline
\end{tabular}

a o cells (.0\%) have expected count less than 5 . The minimum expected count is 29.38 .

The value of $\mathrm{P}<0.05$, hence Null Hypothesis is rejected. This indicates that there is difference in the expectations of collegians and employees on the sub variable.

4. Table 5.30.1 It's common to find a gap between the "initial job description" and "the actual work made to be done on job", and this is a breach of trust * Status Crosstab

\begin{tabular}{|c|c|c|c|c|}
\hline \multirow{2}{*}{\multicolumn{2}{|c|}{$\begin{array}{l}\text { 7.Its common to find a gap between the "initial job } \\
\text { description" and "the actual work made to be done on } \\
\text { job", and this is a breach of trust }\end{array}$}} & \multicolumn{2}{|c|}{ Status } & \multirow{3}{*}{$\begin{array}{r}\text { Total } \\
91\end{array}$} \\
\hline & & \multirow{2}{*}{\begin{tabular}{r|} 
Student \\
55
\end{tabular}} & \multirow{2}{*}{$\begin{array}{r}\text { Professional } \\
36\end{array}$} & \\
\hline Strongly Agree & Count & & & \\
\hline & \% within Status & $9.9 \%$ & $12.5 \%$ & $10.8 \%$ \\
\hline Agree & Count & 185 & 57 & 242 \\
\hline & $\%$ within Status & $33.3 \%$ & $19.8 \%$ & $28.7 \%$ \\
\hline Neither Agree nor & Count & 205 & 90 & 295 \\
\hline
\end{tabular}




\begin{tabular}{|l|l|l|r|r|r|}
\hline & Disagree & & & & \\
\hline & & \% within Status & $36.9 \%$ & $31.3 \%$ & $35.0 \%$ \\
\hline & Disagree & Count & 80 & 78 & 158 \\
\hline & & \% within Status & $14.4 \%$ & $27.1 \%$ & $18.7 \%$ \\
\hline & Strongly Disagree & Count & 30 & 27 & 57 \\
\hline & \% within Status & $5.4 \%$ & $9.4 \%$ & $6.8 \%$ \\
\hline \multicolumn{2}{|l|}{ Total } & Count & 555 & 288 & 843 \\
\hline \multicolumn{2}{|l|}{} & \% within Status & $100.0 \%$ & $100.0 \%$ & $100.0 \%$ \\
\hline
\end{tabular}

Table 5.30.2

Chi-Square Test

\begin{tabular}{|l|r|r|r|}
\hline & \multicolumn{1}{|c|}{ Value } & \multicolumn{1}{c|}{ Df } & \multicolumn{1}{|c|}{ Asymp. Sig. (2-sided) } \\
\hline Pearson Chi-Square & $35.699(a)$ & 4 & $\mathbf{0 0 0}$ \\
\hline Likelihood Ratio & 35.458 & 4 & .000 \\
\hline Linear-by-Linear Association & 13.890 & 1 & .000 \\
\hline N of Valid Cases & 843 & & \\
\hline
\end{tabular}

a o cells $(.0 \%)$ have expected count less than 5 . The minimum expected count is 19.47 .

The value of $\mathrm{P}<0.05$, hence Null Hypothesis is rejected. This indicates that there is difference in the expectations of collegians and employees on this sub variable

5. Table 5.31.1 "Location of job" is no constraint for me, since I am flexible and mobile * Status Crosstab

\begin{tabular}{|c|c|c|c|c|}
\hline \multirow{2}{*}{\multicolumn{2}{|c|}{$\begin{array}{l}\text { 8."Location of job" is no constraint for me ,since I am } \\
\text { flexible and mobile }\end{array}$}} & \multicolumn{2}{|c|}{ Status } & \multirow{3}{*}{$\begin{array}{r}\text { Total } \\
113 \\
\end{array}$} \\
\hline & & \multirow{2}{*}{\begin{tabular}{r|} 
Student \\
65 \\
\end{tabular}} & \multirow{2}{*}{\begin{tabular}{|r|} 
Professional \\
48 \\
\end{tabular}} & \\
\hline Strongly Agree & Count & & & \\
\hline & $\%$ within Status & $11.7 \%$ & $16.7 \%$ & $13.4 \%$ \\
\hline Agree & Count & 220 & 60 & 280 \\
\hline & $\%$ within Status & $39.6 \%$ & $20.8 \%$ & $33.2 \%$ \\
\hline Neither Agree nor Disagree & Count & 115 & 63 & 178 \\
\hline & $\%$ within Status & $20.7 \%$ & $21.9 \%$ & $21.1 \%$ \\
\hline Disagree & Count & 130 & 66 & 196 \\
\hline & $\%$ within Status & $23.4 \%$ & $22.9 \%$ & $23.3 \%$ \\
\hline Strongly Disagree & Count & 25 & 51 & 76 \\
\hline & $\%$ within Status & $4.5 \%$ & $17.7 \%$ & $9.0 \%$ \\
\hline \multirow[t]{2}{*}{ Total } & Count & 555 & 288 & 843 \\
\hline & $\%$ within Status & $100.0 \%$ & $100.0 \%$ & $100.0 \%$ \\
\hline
\end{tabular}


Table 5.31.2

Chi-Square Test

\begin{tabular}{|l|r|r|r|}
\hline & \multicolumn{1}{|c|}{ Value } & \multicolumn{1}{c|}{ Df } & \multicolumn{1}{c|}{ Asymp. Sig. (2-sided) } \\
\hline Pearson Chi-Square & $\mathbf{6 0 . 4 7 0 ( a )}$ & 4 & $\mathbf{0 0 0}$ \\
\hline Likelihood Ratio & 59.503 & 4 & .000 \\
\hline Linear-by-Linear Association & 16.077 & 1 & .000 \\
\hline N of Valid Cases & 843 & & \\
\hline
\end{tabular}

a 0 cells $(.0 \%)$ have expected count less than 5 . The minimum expected count is 25.96 .

The value of $\mathrm{P}<0.05$, hence Null Hypothesis is rejected. This indicates that there is difference in the expectations of collegians and employees on this sub variable.

6. Table 5.32.1 Maternity/ Paternity/ Adoption-leaves/ Sabbaticals Privilege/Casual/and Sick leaves, all should be made available to employees as and when needed * Status Crosstab

\begin{tabular}{|c|c|c|c|c|}
\hline \multirow{2}{*}{\multicolumn{2}{|c|}{$\begin{array}{c}\text { 9.Maternity/Paternity/Adoption leaves/Sabbaticals } \\
\text { Privilege/Casual/and Sick leaves, all should be made available } \\
\text { to employees as and when needed }\end{array}$}} & \multicolumn{2}{|c|}{ Status } & \multirow{3}{*}{$\begin{array}{r}\text { Total } \\
167 \\
\end{array}$} \\
\hline & & \multirow{2}{*}{$\begin{array}{r}\text { Student } \\
125\end{array}$} & \multirow{2}{*}{\begin{tabular}{r|} 
Professional \\
42 \\
\end{tabular}} & \\
\hline Strongly Agree & Count & & & \\
\hline & \% within Status & $22.5 \%$ & $14.6 \%$ & $19.8 \%$ \\
\hline \multirow[t]{2}{*}{ Agree } & Count & 210 & 63 & 273 \\
\hline & \% within Status & $37.8 \%$ & $21.9 \%$ & $32.4 \%$ \\
\hline \multirow[t]{2}{*}{ Neither Agree nor Disagree } & Count & 115 & 84 & 199 \\
\hline & \% within Status & $20.7 \%$ & $29.2 \%$ & $23.6 \%$ \\
\hline \multirow[t]{2}{*}{ Disagree } & Count & 70 & 51 & 121 \\
\hline & \% within Status & $12.6 \%$ & $17.7 \%$ & $14.4 \%$ \\
\hline \multirow[t]{2}{*}{ Strongly Disagree } & Count & 35 & 48 & 83 \\
\hline & \% within Status & $6.3 \%$ & $16.7 \%$ & $9.8 \%$ \\
\hline \multirow[t]{2}{*}{ Total } & Count & 555 & 288 & 843 \\
\hline & \% within Status & $100.0 \%$ & $100.0 \%$ & $100.0 \%$ \\
\hline
\end{tabular}

Table 5.32.2

\section{Chi-Square Test}

\begin{tabular}{|l|r|r|r|}
\hline & \multicolumn{1}{|c|}{ Value } & \multicolumn{1}{c|}{ Df } & \multicolumn{1}{c|}{ Asymp. Sig. (2-sided) } \\
\hline Pearson Chi-Square & $\mathbf{5 0 . 7 8 3 ( a )}$ & $\mathbf{4}$ & $\mathbf{0 0 0}$ \\
\hline Likelihood Ratio & 50.500 & 4 & .000 \\
\hline Linear-by-Linear Association & 41.708 & 1 & .000 \\
\hline N of Valid Cases & 843 & & \\
\hline
\end{tabular}

a o cells $(.0 \%)$ have expected count less than 5 . The minimum expected count is 28.36 . 
The value of $\mathrm{P}<0.05$, hence Null Hypothesis is rejected. This indicates that there is difference in the expectations collegians and employees on this sub variable

7. Table 5.33.1 Discrimination basis Gender, race, marital status still exists at the workplace * Status Crosstab

\begin{tabular}{|c|c|c|c|c|}
\hline \multirow{2}{*}{\multicolumn{2}{|c|}{$\begin{array}{l}\text { 12.Discrimination basis Gender ,race, marital status still } \\
\text { exists at the workplace }\end{array}$}} & \multicolumn{2}{|c|}{ Status } & \multirow{3}{*}{$\begin{array}{r}\text { Total } \\
92 \\
\end{array}$} \\
\hline & & \multirow{2}{*}{\begin{tabular}{r|} 
Student \\
50 \\
\end{tabular}} & \multirow{2}{*}{$\begin{array}{r}\text { Professional } \\
42 \\
\end{array}$} & \\
\hline Strongly Agree & Count & & & \\
\hline & $\%$ within Status & $9.0 \%$ & $14.6 \%$ & $10.9 \%$ \\
\hline Agree & Count & 150 & 81 & 231 \\
\hline & $\%$ within Status & $27.0 \%$ & $28.1 \%$ & $27.4 \%$ \\
\hline Neither Agree nor Disagree & Count & 145 & 90 & 235 \\
\hline & \% within Status & $26.1 \%$ & $31.3 \%$ & $27.9 \%$ \\
\hline Disagree & Count & 135 & 48 & 183 \\
\hline & \% within Status & $24.3 \%$ & $16.7 \%$ & $21.7 \%$ \\
\hline Strongly Disagree & Count & 75 & 27 & 102 \\
\hline & \% within Status & $13.5 \%$ & $9.4 \%$ & $12.1 \%$ \\
\hline \multirow[t]{2}{*}{ Total } & Count & 555 & 288 & 843 \\
\hline & \% within Status & $100.0 \%$ & $100.0 \%$ & $100.0 \%$ \\
\hline
\end{tabular}

Table 5.33.2

Chi-Square Test

\begin{tabular}{|l|r|r|r|}
\hline & \multicolumn{1}{|c|}{ Value } & \multicolumn{1}{|c|}{ Df } & \multicolumn{1}{|c|}{ Asymp. Sig. (2-sided) } \\
\hline Pearson Chi-Square & $\mathbf{1 5 . 0 7 4 ( a )}$ & $\mathbf{4}$ & $\mathbf{0 0 5}$ \\
\hline Likelihood Ratio & 15.163 & 4 & .004 \\
\hline Linear-by-Linear Association & 10.663 & 1 & .001 \\
\hline N of Valid Cases & 843 & & \\
\hline
\end{tabular}

a o cells $(.0 \%)$ have expected count less than 5 . The minimum expected count is 31.43 .

The value of $P$ is 0.05 , hence Null Hypothesis is rejected. Hence there is difference in the expectations collegians and employees on this sub variable.

Table 5.34 Sub -Variables with different expectations between Collegians and Professionals

V1Timely well paid salary "is the deciding factor for me to pick up a job - Working Professionals hold it more important than students

V2 Flexible Work Timings' and "Weekends off" is a motivator for me to pick up a job Professionals give more importance to it than students 
V6."Job security' is not a concern, since there are plenty of jobs around -Students rated it more important.

V7 It's very common to find a gap between the "initial job description" and "the actual work made to be done on job", and this is a breach of trust - Professionals rated it more than students

V8."Location of job" is no constraint for me, since I am flexible and mobile - Professionals have rated it higher than students

V9 Maternity/Paternity/Adoption leaves/Sabbaticals Privilege/Casual/and Sick leaves, all should be made available to employees as and when needed - Professionals hold it more important than students.

V12 Discrimination basis Gender, race, marital status still exists at the workplace. Students have rated it higher than Professionals

Result: Hence for seven out of thirteen sub factors, P value has been either < or = 0.05; hence Null hypothesis is rejected for these seven sub-variables. Therefore the expectations of Gen $\mathrm{Y}$ collegians and Employees vary from each other on these seven aspects.

Table 5.34.1 Sub variables on which expectations are similar between the Collegians and the Professionals:

V3."Health Insurance, Paid Vacation Time, Provident Fund and Retirement benefits" are more important than the monthly "Salary"

V4 Casual Dress Code" is better than the traditional "Formal attire" at the workplace

V5 Work in Teams at the workplace" or "Work from Home" both options should exist at the workplace

V10.Sports Room and Recreation facilities at the work place make me more efficient

V11.Options to work "Part Time" should be made available, if need be

V13. "Grievance Redressal Forums"do give justice, if any injustice happens to me at the work place

\section{Analysis:}


Each of the above variable was discussed as a cross tabulation for the Students and the Professionals: (Refer to Table 5.11 on Ratings and preferences of Students and Professionals presented in descending order)

The Analysis of the table indicates that "Location of the job" being rated as the least important variable both by the Students and Professionals thereby indicating that they are flexible to move, the location of the job and the geographical boundaries would not stop them from working with their preferred employer. Their choices varied on the other four aspects and so does the intensity of their expectations from their employer. For Students "Salary is the first factor, they look into while selecting a Preferred Employer followed by Job security, however the preference of Professionals is just the reverse with "Job security" being first and "Salary" second thereby indicating the importance of Job Security for both of them. This is obvious too, because of the effect of down turn being witnessed in India and across the globe.

Positive work environment was rated the biggest motivator on job for Students while Recognition was rated as the first choice by Professionals since this is what matters the most to them, being recognized and appreciated for the value they bring to the workplace. Having worked for a few years, the choices of Professionals vary from that of Students who still have their expectations rooted into idealistic scenarios. However a similarity was also observed when both rated Flexible working hours as their last choice for motivators. This suggests that they would not mind working for long hours or even $24^{*} 7$, if the work is interesting and they are enjoying it. Results are in sync with another study conducted by Wong et al 2008, which mentions that it is important for organizations to account for the inclination of these youngsters to have a workplace with an environment and culture which is accommodating and which promotes relationship Also an inherent need of these youngsters is to get a job that is challenging as well

Conclusion: In today times, it's the employee, who is defining the workplace and not the employer; their liking, and inclinations are being accounted for in designing the workplace of the future. Employee engagement is given due importance and the rewards and recognition programs are helping the employer in the same. It reinforces positive behavior which assists the firms in the achievement of its goals. A motivated workforce certainly will impact the bottom line positively. The importance of non monetary rewards has increased multifold, rewards need not be expensive and in cash. A pat on the back, a certificate, a trophy, or a hall full of the audience cheering you on your achievements, all works wonders. 
Students rated positive work environment as their first choice. Results are also supported by a study conducted by Lowe et al (2008) Millenials lay importance to the social aspect of work and want a friendly, social and nurturing environment at the workplace. Lyons (2003) also stated that they seek friendly colleagues and a fun environment at work. They prefer collaboration, want to work closely with their colleagues and managers learn from them and in turn respect them and want friendly relationships with the colleagues.

Overall the results are indicative of the fact that the expectations and preferences of Gen Yers with regards to their motivators do change with time. During the In-depth interviews, it was apparent that, when they are actually on work, the reality of circumstances does have its effect on their choices.

\section{References:}

Boyd D (2010) Ethical determinants for generations X and Y. Journal of Business Ethics 93(3): 465-9 BR, K. (2000). Multigeneration employees: strategies for effective management. Oklahoma: Pub Med indexed for Medline.

Bureau, G. o. (Oct 2010). Report on Employment \& Unemployment Survey . Chandigarh.

Corporate Leadership Council(2004).Generation X and $Y$ employees. Washington, DC: Corporate Executive Board.

Corporate Leadership Council (2004)Driving Performance and Retention Through Employee Engagement. UK. Corporate Executive Board

Corporate Leadership Council (2005)HR considerations for engaging Generation $\mathrm{Y}$ employees. Washington, DC: Corporate Executive Board.

Dries, N., Peperman, E., \& De Kerpel, E. (2008). Exploring four generations' beliefs about careers: Is "satisfied" the new"successful”. Journal of Managerial Psychology, 23, 907-928. 0,5

Horeczy, A., Lalani, A., Mendes, G., Miller, M., Samsa, L., Scongack, T. (2011). Leadership preferences of Generation Y.Zugriff am 29.07.2013 und erreichbar unter: http://scholar.googleusercontent.com/scholar?q=cache:CYndWJBnoA8J:scholar.google.c om/\&hl=de\&as_sdt= Maslow A.S (1954) Motivation and Personality, New York: Harper and Row 
Lowe, D., Levitt, K. J., \& Wilson, T. (2008). Solutions for retaining Generation Y employees in the workplace. Business Renaissance Quarterly, 3, 43-57.

Lancaster, L.C \&Stillman, D. (2002). When Generations Collide: Who they are, why they clash, and How to solve the generational puzzle at work. New York: Harper.

Lyons, S. (2003). An exploration of generational values in life and at work. Unpublished doctoral dissertation, Carleton University,Ottawa, ON, Canada.

Mamatha J,Nandini A.S (June 2013 ) Career Expectations of Generation Y IT Employees with Special Reference to Bangalore; Global Journal For Research Analysis, Vol:2, Issue:6

Expectations for Leadership-Generation $Y$ and Innovativeness in the Limelight-By-Susanna Kultalahti, Piia Edinger andTiina Brandt University of Vaasa, Department of Management, Vaasa, Finland

SAGE Publications. (2010, March 10). Work, leisure attitudes of Baby Boomers, Generation Xers and Millennials compared. Science Daily. Retrieved August 24, 2015 from www.sciencedaily.com/releases/2010/03/100310083450.htm

The University of Queensland. (7 Feb 2011). Generation $Y$ as hospitality industry employees-An examination of work attitude differences. Australia: Hospitality Training Association Inc.

Ask Gen Y Research Report, 2007 http://www.askgeny.com/research.php Grail Research 2010.

(October 2009). Gen Y -India. United States: 360 degree Reseach.

(November 2012). HR Horizons

NSSO REPORT 2014

United Nations report on world's employable workforce 2010.

Important Lessons from the Ivory Trenches Journal of Management Inquiry (March 2002) vol. 11 no. 1

Research, A. r. (January 2011). INDIA Raising the growth bar. India.

Research,C.C (2010). Skilling India The Billion People Challenge. India.

Deloitte Consulting Report (2005). Who Are the Millennials, aka Generation Y?

Deloitte (2010). Deloitte Millennial Model.An approach to Gen Y readiness. Deloitte Development LLC.

Differences of different Generations In Indian workforce DOC. TYPE Opinion

DOI: 10.1177/1469787412441289; 28 June 2012 
http://timesofindia.indiatimes.com/business/india-business/Unemployment-levels-rising-in-Indiaexperts-say/articleshow/29403619.cms (Retrieved Jan 26, 2014)

http://indiatoday.intoday.in/story/indian-economy-in-2012/1/166424.html.

http:// www.pewresearch.org.(Retrieved Sept.2012)

http://economictimes.indiatimes.com/topic/Dale-Carnegie (Retrieved 28 June,2015)

http://www.businessworld.in/news/economy/infosys-new-ceo-allows-staff-to-use-twitterfacebook/1545040/page-1(Retrieved Septemeber24,2014). 